\title{
Application of a Reusability Approach in Simulation of Heritage Buildings Performance, Taif- Saudi Arabia
}

\author{
Ali Alzaed* \\ Architectural Engineering Department, Engineering College, Taif University, Taif, 26311, Saudi Arabia
}

A R T I C L E IN F O

Article history:

Received: 26 December, 2020

Accepted: 23 February, 2021

Online: 10 March, 2021

Keywords:

Heritage building

Reusability process and attributes

Thermal comfort

Green restoration

\section{Introduction}

This section is concerned with reviewing and describing the reusability process and its attributes. One of the conservation practice methods that has been used to preserve heritage buildings is to adaptively reuse buildings. Several researchers have stated that reusability in heritage buildings is part and parcel of restoring them. It is considered one of the solutions to revive abandoned or neglected houses, especially in old or historical neighborhoods. In addition, this method can help the designer to document the building. For this reason, understanding reusability and its attributes is an essential demand. It is stated that the change of a historical building's function and renewing it can lead to reuse by the public, as well as making it more sustainable [1]. This type of building has a mixture of cultural and historical values. It is said that there are several heritage buildings worldwide that cannot be used for the same purpose that they were built for [2]. This paper will study reusability and attributes as an approach, on the one hand. After that, the researcher will apply the results of studying this concept to one of the historical buildings in Taif in order to reuse it. That will be by determining the most prominent functional, structural and aesthetic changes, as well as taking into account the environmental, economic and social considerations of the building. In addition to that, the researcher will assess the

*Corresponding Author: Ali Alzaed, Dralzaed@gmail.com

www.astesj.com

https://dx.doi.org/10.25046/aj060216 impact of applying the reusability approach in terms of thermal comfort.

\section{View of the Heritage Housing Buildings in Makkah}

Despite the multiplicity of tourist attractions enjoyed by the Kingdom of Saudi Arabia, archaeological and heritage sites occupy the most prominent place. Due to the kingdom's historical heritage, there are archaeological and heritage sites in different regions of the kingdom, representing a living record of successive civilisations in the Arab region. One of the most prominent regions in Saudi Arabia is Western Region, because it is one of the richest areas for heritage places. Sharbatly House, located in Jeddah at the entrance of Haret Al-Sham on the northern side, is a good example. It consists of four floors built with excavated stone in the year 1350 $\mathrm{AH}$ [3]. This shows the consideration of the environment through selecting local material. There are several heritage buildings, such as Nassif house. It is located in the heart of Jeddah city and it consists of four floors, with beautiful façades adorned with doors, windows and wooden pedals. These worked in a coordinated manner and were decorated with various decorations. This house was built in $1289 \mathrm{AH}$ and was completed in $1298 \mathrm{AH}$, and was built with excavated stone castings in a square shape that was cut from the coast of the Red Sea. It is classified as a high architectural landmark and a witness of the architectural thought of the old style in Jeddah [3]. This house is distinguished by using Red Sea stone, 
which is a local material, and is also unique because of the material of the doors and windows, which has a clear impact in terms of the built environment. Another building, Noor Waly house, is located in the old city of Jeddah, and was built in the year $1280 \mathrm{AH}$. The Islamic Museum is a landmark place located in Makkah, and is a museum specialising in Islamic monuments and Meccan heritage [3]. Its style gives the impression of the prestige of this place. The decoration of this palace was selected to be ecological. Jeddah Municipality Museum is located in Al-Balad district, Jeddah. It has been restored and furnished with many heritage collections that were from people of Jeddah until recently, as well as artefacts dating back to before the Islamic era and pieces from the Islamic era [3]. There is a wide variety of pieces for this place. The Meccan Heritage Museum is located on the ground floor of Tariq Sindi's house. It contains various types of utensils; wooden, metal, and marble tools; Meccan textiles; guns, swords, and daggers, all of which are related to weapons; a number of artefacts, inscriptions, postage stamps, records, and notebooks [3]. Based on the reviews, some of these buildings have changed to become museums or some other use. This gives us a hint about the changeability of the function, which can lead to another successful story.

Alkateb House was later known as Al-Niyabah Palace. This house is located in the Al-Salam neighbourhood in Taif, and it consists of three floors built by Hamad Abdul Wahid, the private writer of the sheriff Aoun Al-Rafeeq in 1315 AH. It became deserted in $1388 \mathrm{AH}$. This building was marked by Roman artistic and architectural influences. It consists of a main foyer, at the end of which are staircase steps with marble stone handrails leading to the upper floors, and at the back, a large irregular orchard [3] and [4]. This building is distinguished by its view and styles, which include several local materials. This link with the local environment is considered as one of the successful opportunities for reuse for a different future activity, such as a café or hotel. Alkaaki House is located in the Al-Salamah neighborhood in Taif, in front of the defence building, and it consists of three floors. It was designed in the Roman style and built in $1358 \mathrm{AH}$. This house is distinguished by its various decorations and ceilings, and there is a garden in the rear belonging to it. There is also a section for men for women, known as the Harmalik and Selimk [4]. There are many experiences that have been applied to reusing heritage buildings in historical cities. The historical city of Erbil is an example, where the author mentioned the importance of having balance between conservation and reuse of these kinds of building [5]. The location of the selected case study and its design concept shows the possibility of adaptive reuse in the future as a commercial activity. This will be verified by applying the methodologies as described in the next section.

\section{Methodology}

The research paper uses several methods, as follows:

- Reviewing the heritage building background in the Western Region of KSA, and the reusability approach and its attributes.

- Developing and adopting reusability as a process and as attributes for green restoration of traditional buildings in Taif City, in keeping with its traditional character. This demands documenting the building using several methods such as AutoCAD, Survey and Photo Snap to assess the current situation.
- Assessing the impact of using a reusability approach on thermal comfort through using one of the most powerful energy building tools (TAS EDSL) [6].

\section{Reusability Process and Attributes}

Reusability as a process has been developed by several researchers. One of them developed a proposed iterative process model [7]. The process of this model for reuse-oriented software is reusability. This model consists of five stages as follows: Stage (1) Planning Phase: to study the expected profits in terms of technical aspects, reducing the cost of management and development [7]. Stage (2) Risk Analysis: this stage has two approaches which are reactive and proactive [7]. Each one of them has several features. Proactive features are the domain stable which means it is easy to invest directly for reuse and easy to predict the product features. However, reactive features mean it can be developed based on what is required. This approach is how to reengineer and adjust the current assets. Stage (3) Core Asset Development and Evolution: this includes determination and definition of features while understanding the similarities and differences between them. Furthermore, extension of the architecture if there is a clear demand and addressing the conflicts between the quality and product functionality. Stage (4) Change Requirement and Adaptation: a new requirement that will lead to changing the technology and environment. This usually will be during development work which is not expected. For this reason, the software has to be adapted to that and capable of managing it. Stage (5) Customer Evaluation: observation of the feedback of the customer [7]. To apply these terminologies and approach, there is a clear demand to understand what the main attributes of the reusability concept are, to be the basis for more understanding of this philosophy. This will give the research a clear vision about the possibility of its application on restoration of buildings. The main attributes are illustrated in Table 1:

Table 1: Reusability Attributes

\begin{tabular}{|l|l|l|}
\hline Attribute & Description & References \\
\hline Flexibility & $\begin{array}{l}\text { Easily modify a system or } \\
\text { component for new uses, } \\
\text { different from what it was } \\
\text { originally designed for. }\end{array}$ & [9] \\
\hline Maintainability & $\begin{array}{l}\text { Easy-maintenance software } \\
\text { system or component to add } \\
\text { capabilities or change or } \\
\text { correct faults. }\end{array}$ & \\
\hline Portability & $\begin{array}{l}\text { No external support is } \\
\text { required to perform the } \\
\text { functions, and has the } \\
\text { ability to use alternative } \\
\text { solutions at any time. }\end{array}$ & \\
\hline Variability & $\begin{array}{l}\text { The ability of a component } \\
\text { to be configured which } \\
\text { helps to decrease } \\
\text { understandability. }\end{array}$ & {$[8]$} \\
\hline Understandability & $\begin{array}{l}\text { Can also be defined as the } \\
\text { level of understanding of } \\
\text { the system's way of } \\
\text { working. }\end{array}$ & \\
\hline
\end{tabular}




\begin{tabular}{|l|l|l|}
\hline Size & $\begin{array}{l}\text { The lines of code and length } \\
\text { of the software. }\end{array}$ & [8] and [9] \\
\hline Complexity & $\begin{array}{l}\text { The difficulty in } \\
\text { understanding the design } \\
\text { and implementation of } \\
\text { software, which means } \\
\text { reusing complex software. }\end{array}$ & \\
\hline Scope coverage & $\begin{array}{l}\text { The number of features that } \\
\text { the component provides } \\
\text { through a particular feature. }\end{array}$ & \\
\hline Availability & $\begin{array}{l}\text { How easy it is to retrieve a } \\
\text { software component. }\end{array}$ & {$[10]$} \\
\hline
\end{tabular}

\section{Reusability Process and Attributes for Green Heritage Building}

In this research, selecting reusability as process and attributes may help designers to study and evaluate the feasibility of any building reuse. The current status of a green heritage building will be evident in the following case of a heritage building in the historic center of Taif. However, the process that has been adopted is shown in Figure 1.

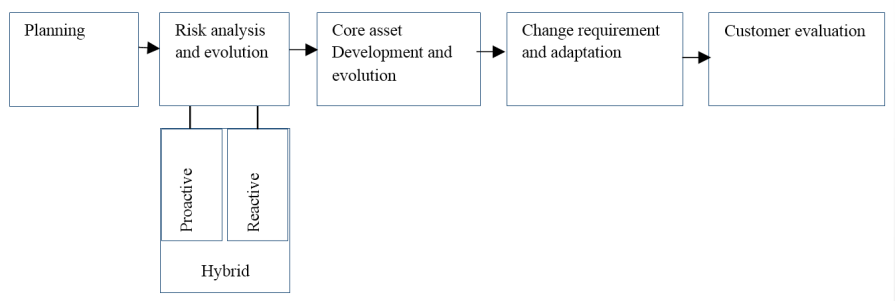

Figure 1: Reusability process

\subsection{In terms of planning stage}

In this stage the building was abandoned. For this reason, to assess the benefit of restoring this building, the designer has to understand its main previous function and its retirement. In addition, it has to minimize the cost of development as well as its future management. As a result, there was a clear demand to document this heritage building as a study case for this research. For this reason, the building has been visited and surveyed to discover its boundary and investigate the environmental conditions as shown in Table 2.

Table 2: Survey points

\begin{tabular}{|l|l|l|}
\hline Points & E & N \\
\hline 1 & 40.4081340 & 21.2749090 \\
\hline 2 & 40.4080430 & 21.2748770 \\
\hline 3 & 40.4080660 & 21.2748220 \\
\hline 4 & 40.4081550 & 21.2748530 \\
\hline
\end{tabular}

In addition, it is important to understand the previous function of the building, which was residential. For this reason, there is a clear demand to know the building components, elements and features. This was done through a manual documentation device which was used to draw building floors using AutoCAD software. All building floors were accessed by natural ventilation and daylighting, except one zone in the ground floor, as shown in Figure2.

\subsection{Risk Analysis Stage}

Rethinking the new use of the building was done through meeting with the building investors. They were confused about the optimal use that would bring them economic returns because housing investment was not encouraging for them, compared to similar experiences in the same location. It was considered that there were no museums in the city center, which could be an ideal option. However, one of the main landmarks of Taif City is Shubra Palace Museum, not far from their location. For this reason, the decision was to make the museum with a special and distinctive style. This is in terms of identification of the proposed activity, on the one hand. On the other hand, in terms of the building it has to be identified if it is proactive or reactive. In terms of being proactive, the building is stable and reliable and only needs a low budget. At the same time, the building can be reactive as there is a demand for some adjustment and reconfiguration in the ground floor, as shown in Figure2 and Figure3.
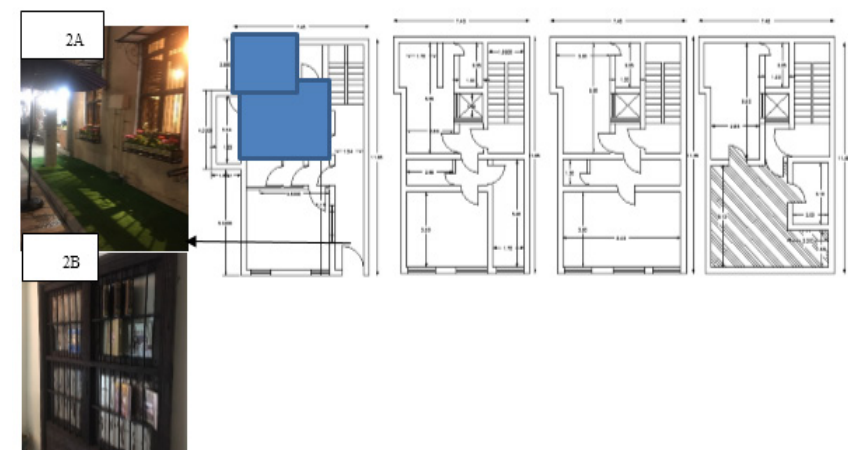

Figure 2 : Building floors.

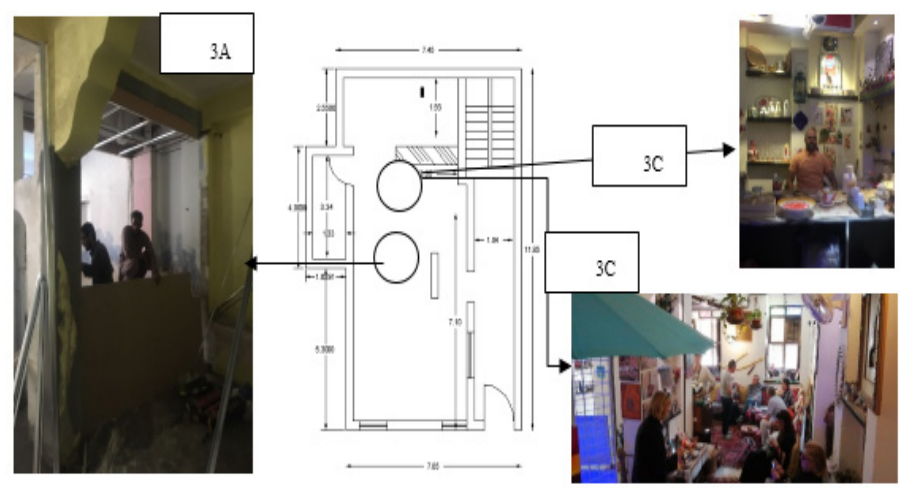

Figure 3: Ground floor before and after restoration

\subsection{Core asset development and evolution}

The decision was to make the museum with a special and distinctive style. This is in terms of identification of the proposed activity, on the one hand. In addition to that, the building has several attributes that support the decision. In the first place, the building style is heritage. This is obvious on the building facade which includes roshanah, which is the window made from wood. In terms of the interior, the building is capable of being a museum, as there were cavities on the wall as well as shelves. Most of the attributes considered during restoration are mentioned with more explanation, as indicated in Table 3. In addition to that, the ground floor zones have been mixed to be one zone as shown in Figure3. 
The natural ventilation and daylighting did not reach the back section, which means it was not suitable for the future user.

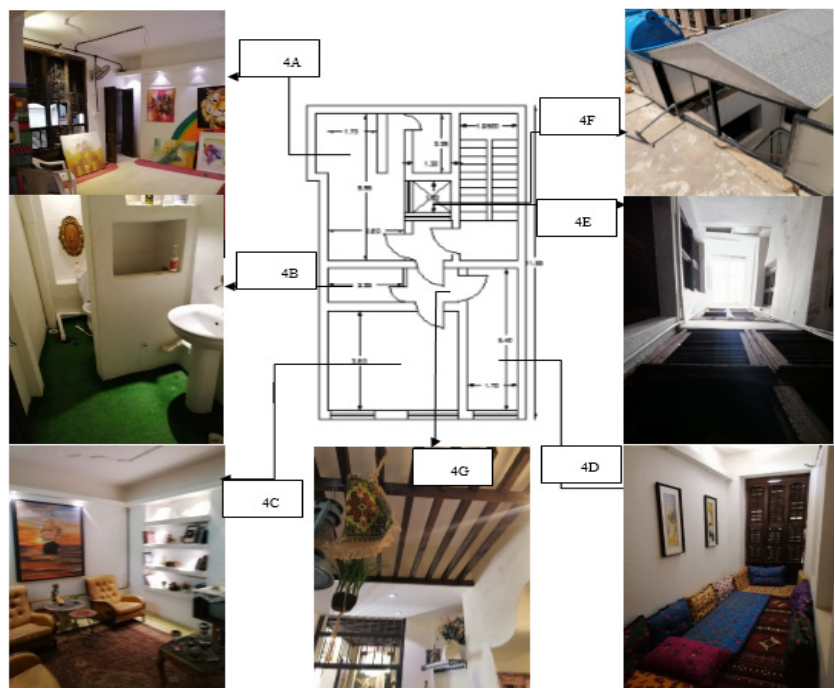

Figure 4: Second floor restoration

\subsection{Change requirement and adaptation}

This happened during the building use and activation. Some of the zones have had their functions changed to be galleries, following which signs and paths on the floors were created to assist visitors. In addition, the ground floor has adapted a café to enhance activity for the museum which provides a service to visitors. The roof use has been changed to become a painting studio. All of these additions were after the building was set up with its new activity as a museum.

\subsection{Customer evaluation}

The overall impression of the visitors was very positive. This was evident by their enjoyment of the experience. In addition to the diversity found in the building is a café for hospitality, an art gallery, a drawing studio and a museum. All these factors enhance the visitor experience. A limitation that helps measure user satisfaction is the thermal comfort of buildings. Therefore the interior temperature of the building was evaluated before and after the restoration using the simulation software (TAS) as mentioned in the research methodology. The results of that will be explained in the following sections, and the building material and location description is shown in Table 4.

Table 3: Reusability green heritage attributes

\begin{tabular}{|l|l|}
\hline \multicolumn{1}{|c|}{ Attributes } & \multicolumn{1}{c|}{ Descriptions } \\
\hline Flexibility & $\begin{array}{l}\text { The designer removed the wall in the } \\
\text { ground floor to have a large space and to } \\
\text { let the air and light access the whole area, } \\
\text { as highlighted in Figure 2 and illustrated } \\
\text { in Figure 3. In addition, the skylight is } \\
\text { adopted as the main hole as shown in } \\
\text { Figure 4 (4E-4F), as well as the main wall } \\
\text { being used for shelves as illustrated in } \\
\text { Figure 4 (4C) and the staircase used as a } \\
\text { store. }\end{array}$ \\
\hline
\end{tabular}

\begin{tabular}{|c|c|}
\hline Maintainability & $\begin{array}{l}\text { External electrical installations as shown } \\
\text { in Figure } 4(4 \mathrm{~A}) \text {. Plant pots easy to install, } \\
\text { remove and maintain. }\end{array}$ \\
\hline Portability & $\begin{array}{l}\text { Fans and industrial lighting as shown in } \\
\text { Figure } 2(2 \mathrm{~A}) \text {. }\end{array}$ \\
\hline Variability & $\begin{array}{l}\text { The designer created the paths for the } \\
\text { gallery as a guide, as in Figure } 4 \text { (4A). } \\
\text { Indicative maps and configuration of the } \\
\text { building were based on user needs, such } \\
\text { as modifying the gallery to be a hospitality } \\
\text { salon as shown in Figs. } 4 \mathrm{C} \text { and } 4 \mathrm{D} \text {, and } \\
\text { using the heritage window (oriel window) } \\
\text { to be bookshelves as shown in Figure 2B. }\end{array}$ \\
\hline Understandability & $\begin{array}{l}\text { Features of the rooms, ways of furnishing } \\
\text { them and the building map in the } \\
\text { distribution of its elements. }\end{array}$ \\
\hline Size & $\begin{array}{l}\text { Removing the wall of the ground floor and } \\
\text { adding shade shelters as shown in Figure } \\
\text { 2A. Some decorations on building façades } \\
\text { may also fulfill an ecological function } \\
\text { [11]. Agricultural ponds, wooden } \\
\text { pergolas, shelves and gypsum decorations } \\
\text { as shown in Figure } 4 \mathrm{G} \text {. }\end{array}$ \\
\hline Complexity & $\begin{array}{l}\text { Narrow space and lack of ventilation and } \\
\text { lighting for some spaces; floors on the } \\
\text { ground floor have more than one level; the } \\
\text { electricity network was irregular and } \\
\text { random; and the bathrooms were not } \\
\text { suitable. }\end{array}$ \\
\hline Scope coverage & $\begin{array}{l}\text { - Outside coverage; turn it into an } \\
\text { attraction. } \\
\text { - Choose the right function. } \\
\text { - Configure building activity from } \\
\text { house to museum. } \\
\text { - Enhance the returns through the } \\
\text { configuration based on a coffee place, } \\
\text { as shown in Figure 3C, and gallery } \\
\text { (Figure 4A). Rent the rooms as } \\
\text { hospitality places and ticketed areas, } \\
\text { and configure the main roof as a } \\
\text { painting studio. }\end{array}$ \\
\hline Availability & $\begin{array}{l}\text { All restorations and additions, such as } \\
\text { removable wall, skylight as illustrated ( } 4 \mathrm{E} \\
\text { and } 4 \mathrm{~F} \text { ), and shelters on the main door and } \\
\text { windows as shown in } 2 \mathrm{~A} \text {, are easy to } \\
\text { remove and restore the building to its } \\
\text { previous use. }\end{array}$ \\
\hline
\end{tabular}

\section{Numerical Simulation}

Distinctive physical models are utilized to depict the structure warm conduct contingent upon their particular needs, counting space warming, ventilation, cooling frameworks, inhabitants' practices, and budgetary viewpoints. The physical structure execution depends on the unraveling of the warmth move 
differential conditions, which can be written regarding the energy preservation law:

$$
Q_{\text {int }}+Q_{\text {source }}=Q_{\text {out }}+Q_{\text {stock }}
$$

Where Qint is the heat flux entering the system, Qsource the heat flux of an eventual heat source, Qout the heat flux leaving the system and Qstock the heat flux stored. The principal in and outcoming fluxes taking place in the heat transfer are the conduction through walls, the convection (both sensible and latent heat), the radiation and the ventilation.

Countless mathematical virtual products are these days accessible to take care of such physical issues, both in fixed and dynamic conditions. The consistent state approach is ordinarily used to survey the structure energy execution and prompts long haul examinations of various situations thank to their quick computations. In any case, a significant constraint happens since the dormancy of the structure envelope is totally disregarded. Consequently, dynamic warm models ought to be favored while breaking down energy sparing arrangements.

Building demonstrating and reproduction programming TAS was utilized to foresee energy execution, improve warm and subsequently inhabitant comfort (EDSL TAS 2017). The documents used to finish the model on TAS are the arrangement sees appeared in Figure 2. At first, the model made on TAS was an imitation of the current condition of the building. Hence, the underlying produced energy model was the reference point for enhancements.

In the present study, the following modelling assumptions are adopted:

1. It was expected that the residence is involved from $6 \mathrm{pm}-$ 8 am during non-weekend days and for an entire 24 hours during the end of the week.

2. The programmed recreation of characteristic ventilation (due to windows, entryways, ventilators, and different gaps comparative with their elevation and direction) will be thought to be the reasonable portrayal of the real wind stream (EDSL TAS 2017).

3. The National Calculation Method (NCM) information base will be utilized to apply to all zones (EDSL TAS 2017).

4. The development of the TAS model is dependent on compositional drawings (Figure2). In any case, to improve the model the impact of the encompassing trees was not considered in this reproduction. At first, utilizing the accessible design drawings of the genuine structure, the floor plans were attracted the 3D-TAS. The following stage in the model improvement was to characterize zones inside each floor for warm reproduction purposes. This zone definition was critical as it impact the manner in which the model would be dissected. The indoor warm exhibition of the building, especially identified with more elevated level warm definition, was essentially estimated and investigated by contrasting the hourly normal indoor air temperature and mean brilliant temperature of zones.

These days, there are two principle ways to deal with gauge human warm solace Predicted Mean Vote (PMV) furthermore, the
Percentage of Dissatisfied (PPD). These methodologies which consider a few ecological viewpoints, for example, dry bulb temperature, moistness, air speed and mean brilliant temperature (Figure 5) just as human factors, for example, warm obstruction and metabolic rate. Warm balance is inferred when the interior warmth creation in the body is equivalent to the warmth misfortune to the encompassing climate [12].

In the present study, the thermal conductivity (Watt $/ \mathrm{m} 2 . \mathrm{K}$ ) is assumed to be constant for any given material, and is independent of temperature; i.e.

$$
\lambda=\frac{q}{A\left(T_{1}-T_{2}\right)}
$$

The U-value for a certain structure is expressed as the ratio of the density of heat flow rate through the structure $\mathrm{q}, \mathrm{W} / \mathrm{m} 2$, and the difference between the internal and external temperature values, as follows:

$$
U=\frac{q}{\left(T_{i}-T_{e}\right)}
$$

It will be accepted that the Location properties of the designed building are the real current states of the building (Table 4).
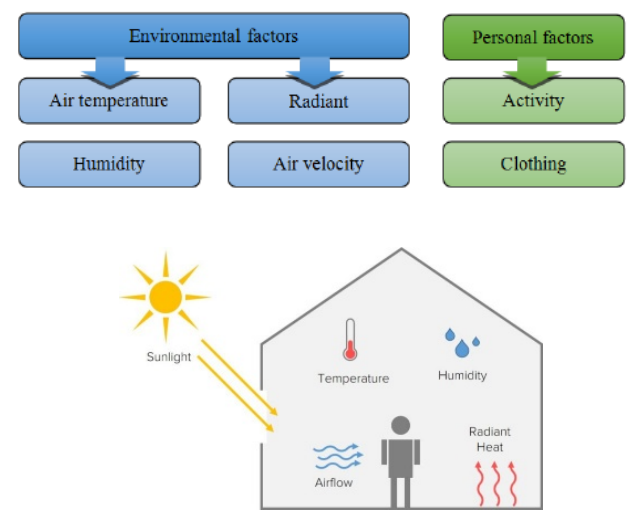

Figure 5: The important factors affecting thermal comfort in the two approaches (PMV and PPD) [13]

Table 4: Location properties of the designed building (Taif City) and green heritage building material

\begin{tabular}{|l|l|l|}
\hline \multicolumn{3}{|l|}{ Location properties of the designed building (Taif City) } \\
\hline No & Property & Description \\
\hline 1 & Location & $\begin{array}{l}\text { Downtown Taif, } \\
\text { Saudi Arabia }\end{array}$ \\
\hline 2 & Latitude & $21.44^{\circ} \mathrm{N}$ \\
\hline 3 & Longitude & $40.51^{\circ} \mathrm{E}$ \\
\hline 4 & Elevation & $1700.0 \mathrm{~m}$ \\
\hline 5 & $\begin{array}{l}\text { Daily lower average air } \\
\text { temperature }\end{array}$ & $10.9^{\circ} \mathrm{C}$ \\
\hline 6 & $\begin{array}{l}\text { Daily upper average air } \\
\text { temperature }\end{array}$ & $32.0^{\circ} \mathrm{C}$ \\
\hline
\end{tabular}




\begin{tabular}{|c|c|c|c|c|}
\hline 7 & \multicolumn{3}{|c|}{ Average air flow speed } & $3.8 \mathrm{~m} / \mathrm{s}$ \\
\hline 8 & \multicolumn{2}{|c|}{ Relative humidity } & & $46 \%$ \\
\hline \multicolumn{5}{|c|}{ Building materials } \\
\hline & Layer & $\begin{array}{l}\text { Width } \\
(\mathrm{mm})\end{array}$ & $\begin{array}{l}\text { Conductivit } \\
\mathrm{y} \\
\left(\mathrm{W} / \mathrm{m}^{2} .{ }^{\circ} \mathrm{C}\right)\end{array}$ & $\begin{array}{l}\text { Total } \mathrm{U} \\
\text { value } \\
\left(\mathrm{W} / \mathrm{m}^{2} .{ }^{\circ} \mathrm{C}\right. \\
)^{2}\end{array}$ \\
\hline $\begin{array}{l}\text { External } \\
\text { wall }\end{array}$ & Block & 300 & 0.25 & 0.73 \\
\hline \multirow[t]{3}{*}{ Ground } & Sand dry & 1000 & 0.329 & \multirow[t]{3}{*}{0.286} \\
\hline & $\begin{array}{l}\text { Crushed } \\
\text { aggregat } \\
\mathrm{e}\end{array}$ & 75 & 0.55 & \\
\hline & Concrete & 150 & 0.87 & \\
\hline \multirow[t]{2}{*}{ Roof } & $\begin{array}{l}\text { Polystyre } \\
\text { ne } \\
\text { expanded } \\
\text { sheet }\end{array}$ & 125 & 0.04 & \multirow[t]{2}{*}{0.297} \\
\hline & Concrete & 100 & 1.45 & \\
\hline Shading & $\begin{array}{l}\text { Wooden } \\
\text { shading }\end{array}$ & 10 & 0.14 & 2.848 \\
\hline \multirow[t]{4}{*}{ Glazing } & $\begin{array}{l}\text { Type of } \\
\text { glazing }\end{array}$ & $\begin{array}{l}\text { Width } \\
\text { (mm) }\end{array}$ & $\begin{array}{l}\text { Solar } \\
\text { reflectance }\end{array}$ & $\begin{array}{l}\text { Solar } \\
\text { absorptio } \\
\mathrm{n}\end{array}$ \\
\hline & Single & 10 & 0.070 & \multirow[t]{3}{*}{0.115} \\
\hline & $\begin{array}{l}\text { Solar } \\
\text { transmitt } \\
\text { ance }\end{array}$ & $\begin{array}{l}\text { Emissivit } \\
\mathrm{y}\end{array}$ & $\begin{array}{l}\text { Total } \mathrm{U} \\
\text { value } \\
\left(\mathrm{W} / \mathrm{m}^{2} .{ }^{\circ} \mathrm{C}\right)\end{array}$ & \\
\hline & 0.70 & 0.845 & 5.681 & \\
\hline
\end{tabular}

performance. During the wintertime, the outdoor temperature was 13.8 degrees and the indoor air temperature for hall 1 and hall 2 were 14.3 and 20.29 degrees, respectively. However, after reconfiguration of the ground floor, the indoor air temperature become 14.04 degrees, which is still higher than the outdoor temperature, as illustrated in Figure8.

The discussion above illustrates that the reusability building approach and reconfiguration can have a clear impact on the interior thermal comfort. In addition, the restorations of the design and application of some techniques such as a wind catcher can lead to improving the interior energy without any mechanical demands. Using these approaches and passive techniques is more beneficial than a huge restorations of the building, especially in heritage buildings.

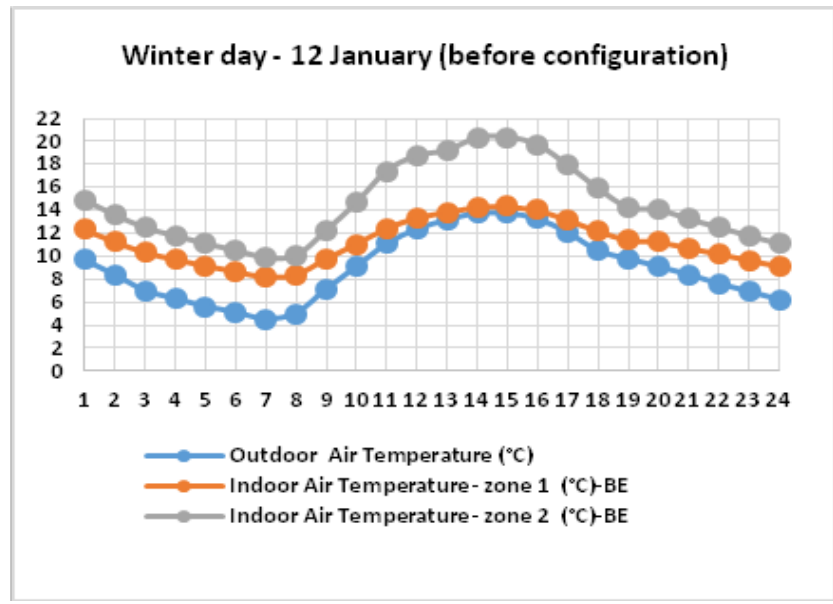

\section{Results and Discussion}

With respect to the impact of the reusability approach on the built environment, the main changes that have been made are to reconfigure the ground floor to be one zone, as well as to install a skylight to be a wind catcher. These simple treatments were used due to the moderate climate of Taif. In contrast to hot, dry climates that require some different treatments. An example is the evaporative cooling that was tested on an apartment building in Baghdad [14]. All these measures can lead to enhancing the thermal comfort of the building. Before the reconfiguration of the building design and through the summer season, the outdoor air temperature was 35.6 degrees at $2.00 \mathrm{pm}$ and the indoor air temperature for hall one was 34.54 degrees, almost one degree different, while hall 2 was 42.87 degrees at the same time, as shown in Figure6. However, after the reconfiguration, the ground floor became one zone. The indoor air temperature becomes 33.33 degrees, which means that it decreased by approximately one degree, as shown in Figure7. This gives a clear indication of the impact of the reusability approach through mixing the zones on improving the thermal comfort for the end user. In addition, the wind catcher can add value to that and enhance the thermal comfort

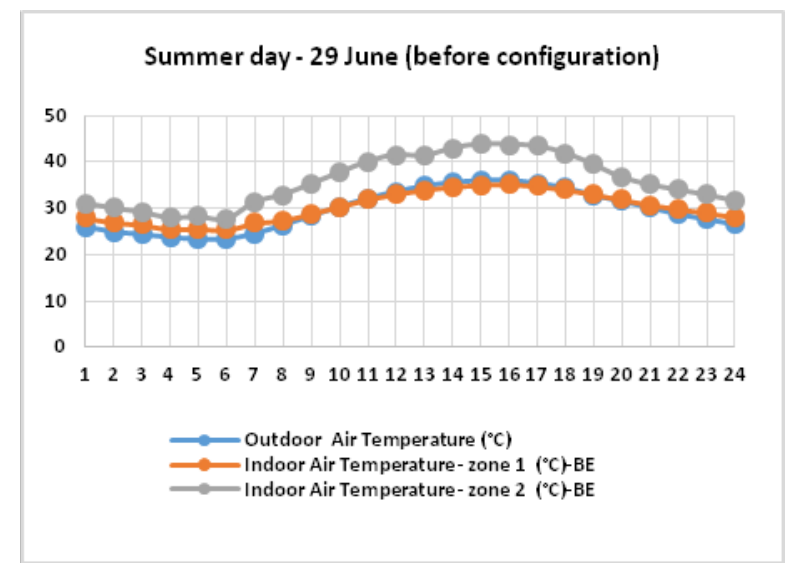

Figure 6: The result of outdoor and indoor temperature before configuration

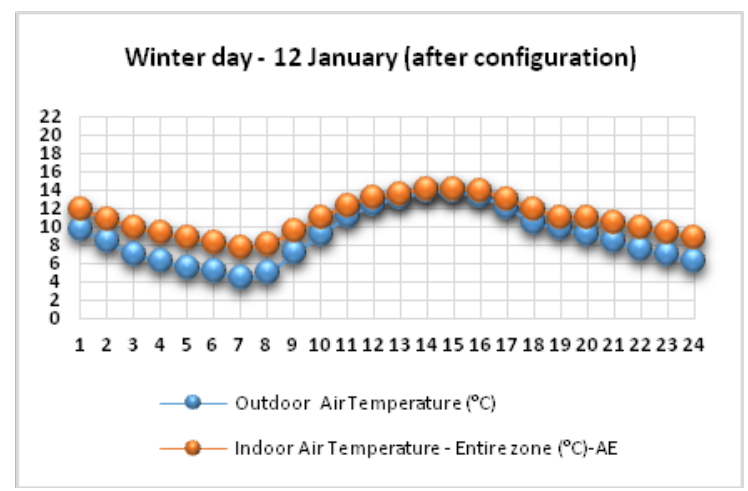

www.astesj.com 


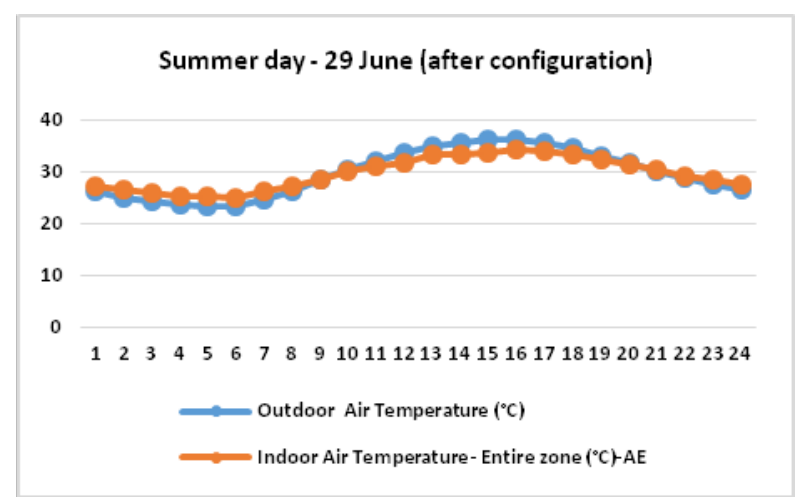

Figure 7: The result of outdoor and indoor temperature after configuration
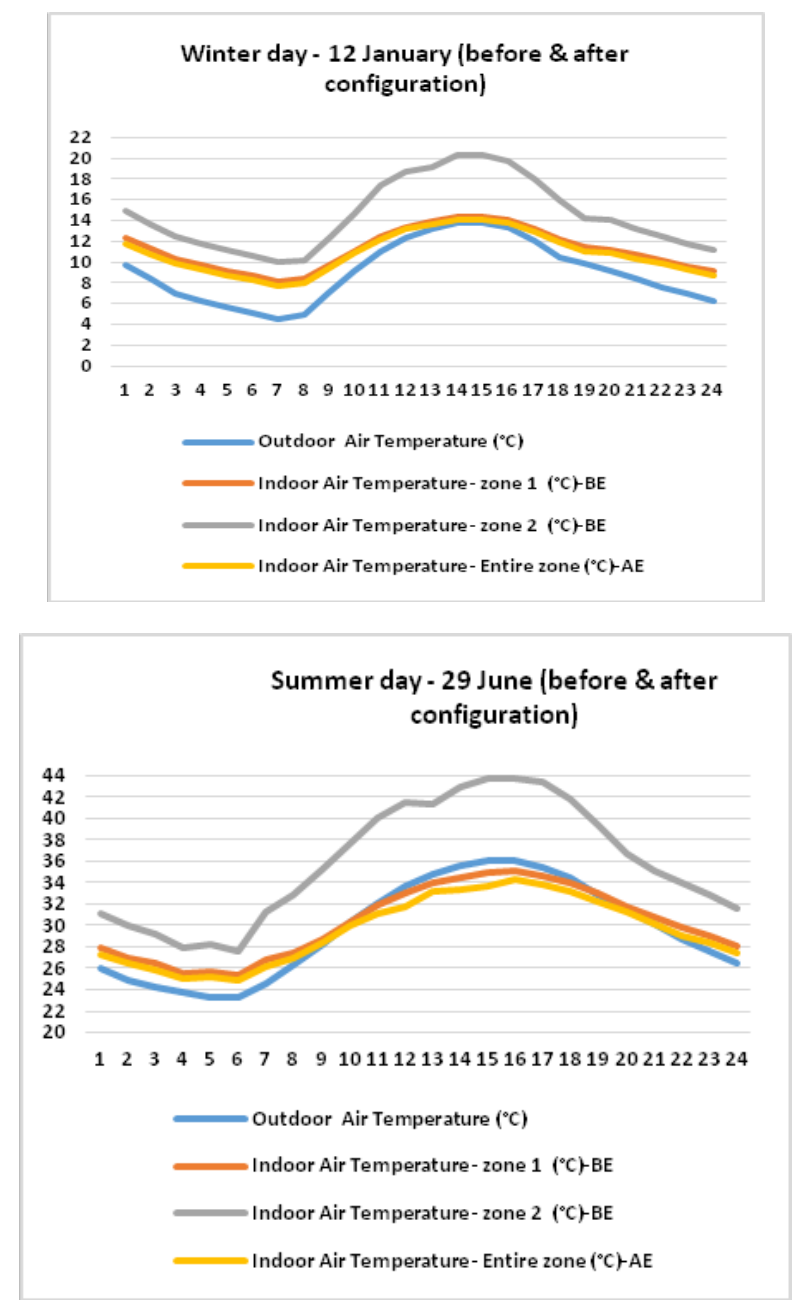

Figure 8: The result of outdoor and indoor temperature before and after configuration

\section{Conclusions}

The work of this research investigated the impact of using the reusability approach on the building restoration, usage and performance. This was clear in a hot and cold climate in Taif City. Usage of local material, a wind catcher, and reconfiguration of the interior design were investigated. One of the obvious results is the effect whereby the reusability approach can lead to a decrease in the interior temperature by two degrees in hot climates. In addition, using the reusability approach with some passive techniques is more beneficial than a huge design reconfiguration. The numerical simulation results indicated that due to the restoration process adopted, there is a decrease in the inside temperature of the building. However, the small value of temperature reduction can be referred to the nice weather of Taif city, where the heritage building found. The most important conclusion is such restoration can lead to temperature reduction. Any way, we think that such restoration process might be important in hot weather cities.

\section{References}

[1] M. Ulusoy, E. Erdogan, H. Erdoğan, M. Oral, "RE-USING OF THE HISTORICAL BUILDINGS IN THE CONTEXT OF SUSTAINABLITY: AN ARCHITECTURAL DESIGN STUDIO STUDY ON OLD GIRLS TEACHER TRAINING SCHOOL," in ISPRS - International Archives of the Photogrammetry, Remote Sensing and Spatial Information Sciences, 2013, doi:10.5194/isprsarchives-XL-5-W2-653-2013.

[2] R. Ghada, R. Amany, A.R. Riham, "Adaptive Re-Use and Sustainable Development for Existing Historic Buildings - Case Study: Buildings of Racetrack Horses in Sporting Club, Alexandria, Egypt," International Journal of Current Engineering and Technology, 7(4), 1523-1530, 2017.

[3] A. N., Archaeological lexicon of the province of Makkah. Makkah, K.S.A, Commission publications in the revitalization of tourism Taif: 176-190, 2003

[4] A. N., Archaeological lexicon of the province of Taif. Taif, K.S.A, Commission publications in the revitalization of tourism Taif: 109-129, 2002.

[5] A. Abbas, B. Khaznadar, "Using Adaptive Reuse as a strategy for the renovation of traditional vernacular architecture in Erbil city," 2019.

[6] EDSL. Tas, Available: Https://Www.Edsltas.Com,.

[7] J. K.s, D. Vasantha, "A New Process Model For Reuse Based Software Development Approach," Lecture Notes in Engineering and Computer Science, 2170, 2008.

[8] A.K. Mahmood, "Reusability Assessment of Open Source Components for Software Product Lines," International Journal of New Computer Architectures and Their Applications (IJNCAA), 3, 519-533, 2011.

[9] C. Monga, A. Jatain, D. Gaur, "Impact of quality attributes on software reusability and metrics to assess these attributes," in 2014 IEEE International Advance Computing Conference (IACC), 1430-1434, 2014, doi:10.1109/IAdCC.2014.6779536.

[10] D. Hristov, O. Hummel, M. Huq, W. Janjic, "Structuring Software Reusability Metrics for Component-Based Software Development," International Conference Software Engineering Advances, (c), 421-429, 2012.

[11] F. Alasadi, G. Al Slik, "Ornamentation and Modern Architecture in Iraq," Journal of Engineering, 25, 117-124, 2019, doi:10.31026/j.eng.2019.06.09.

[12] ISO 7730:2005(en) Ergonomics of the thermal environment - Analytical determination and interpretation of thermal comfort using calculation of the PMV and PPD indices and local thermal comfort criteria, 2005.

[13] Quick Guide: Overheating and Thermal Comfort, Available: Https://Ggbec.Co.Uk/Quick-Guide-Overheating-Thermal-Comfort/,.

[14] A. Alhosainy, I. Aljubury, "Two Stage Evaporative Cooling of Residential Building Using Geothermal Energy," Journal of Engineering, 25(4), 29-44, 2019, doi:10.31026/j.eng.2019.04.03.

- 